\title{
Ethnobotany in the Cumbres de Monterrey National Park, Nuevo
} León, México

\author{
Eduardo Estrada*1, José A Villarreal ${ }^{2}$, César Cantú1 ${ }^{1}$, Ismael Cabral ${ }^{1}$, \\ Laura Scott ${ }^{1}$ and Carmen Yen ${ }^{1}$
}

Address: ${ }^{1}$ Facultad de Ciencias Forestales, Universidad Autónoma de Nuevo León, km 145 Carretera Nacional Linares-Cd. Victoria, A.P. 41, 67700, Linares, N.L., México and ²Departamento de Botánica, Universidad Autónoma Agraria Antonio Narro, Buenavista, Saltillo, Coahuila 25315, México

Email: Eduardo Estrada* - aeduardoestradac@prodigy.net.mx; José A Villarreal - javq00@yahoo.com.mx; César Cantú - ccantu@fcf.uanl.mx; Ismael Cabral - icabralc@gmail.com; Laura Scott - lscott@fff.uanl.mx; Carmen Yen - cyen100@hotmail.com

* Corresponding author

Published: 30 January 2007

Journal of Ethnobiology and Ethnomedicine 2007, 3:8 doi:10.1 186/1746-4269-3-8

This article is available from: http://www.ethnobiomed.com/content/3/l/8

(C) 2007 Estrada C et al; licensee BioMed Central Ltd.

This is an Open Access article distributed under the terms of the Creative Commons Attribution License (http://creativecommons.org/licenses/by/2.0), which permits unrestricted use, distribution, and reproduction in any medium, provided the original work is properly cited.

\begin{abstract}
An ethnobotanical study in the Cumbres de Monterrey National Park (CMNP), Nuevo Leon, Mexico was conducted. In spite of the large area $(I, 773.7 \mathrm{~km} 2)$, heterogeneous physiography, contrasting plant communities and high species diversity of the CMNP, very little was previously known about its useful plants. Based on 95 interviews with inhabitants of the region who were 35 years or older, we recorded ethnobotanical data of 240 species (comprising 170 genera and 69 botanical families), and I 46 different uses. Most of the cited uses (98) were found to be medicinal ones.
\end{abstract}

Background: An ethnobotanical study in the Cumbres de Monterrey National Park (CMNP), Nuevo Leon, Mexico was conducted. In spite of the large area $\left(1,773.7 \mathrm{~km}^{2}\right)$, heterogeneous physiography, contrasting plant communities and high species diversity of the CMNP, very little was previously known about its useful plants. Based on 95 interviews with inhabitants of the region who were 35 years old or older, we recorded ethnobotanical data of 240 species (comprising 170 genera and 69 botanical families), and I 46 different uses. Most of the cited uses (98) were found to be medicinal ones.

Methods: Ninety five inhabitants 35 years old and oldest were interviewed to know what are the main plant uses in the Cumbres de Monterrey National Park.

Results and discussion: Two hundred and forty species, 170 genera, and 69 families of useful plants and I 46 different uses were recorded. We found most of the uses to be medicinal (98), while the rest (48) represent various purposes. Herbaceous plants are the most used, followed by shrubs and trees.

\section{Background}

Northeastern Mexico presents a high diversity of plant associations, including a variety of scrubland types (Tam- aulipan, xerophyllous, rosetophyllous and piedmont communities) [1][2][3], chaparral [4], mixed pine-oak forest [3][5], conifer forest [3][6][7][8], halophytic grass- 
lands [9], and alpine meadows [7][10]. Many of these plant communities are currently under threat because of frequent forest fires, deforestation, conversion of natural vegetation into cattle pastures, croplands and fruit orchards, and extensive clearing for human settlements. One of the most significant physiographic units in northeastern Mexico is the Sierra Madre Oriental because of is role in moisture catchment and watershed management, and because it sustains extensive conifer and oak forests, which are the main forest resources of the region. The high plant diversity and scenic beauty of these mountains have merited the establishment of a number of natural protected areas, such as El Cielo Biosphere Reserve, Cumbres de Monterrey National Park, Cerro El Potosí Natural Protected Area and El Tokio Natural Protected Area, among others.

Employment of medicinal or useful plants is a common activity all over Mexico, and, may be closely related to worsening economic conditions [11]. A lack of medical care, unsanitary conditions, malnutrition, and poverty wages [12], together with high cost of medicines had contributed to people's need to use both traditional and modern health care, including medicinal plants. Abundant information about useful plants in Mexico recorded from the mesomaerican tropical south region $[13][14][15][16][17][18][19][20]$ shows the relevance and legacy of the huge knowledge about different plant uses and applications, now widely used in northern areas.

Cumbres de Monterrey is the largest national park in Mexico, covering an area of 177,367 hectares $\left(1,773.7 \mathrm{~km}^{2}\right)$. It was established in 1939 by presidential decree to preserve the regional flora and fauna, and today it remains one of the most visited areas in the central part of the State of Nuevo León for picnics, hiking, camping and other recreational activities. The main villages inside the Park are Puerto Genovevo, El Manzano, Ciénega de González, Laguna de Sánchez, El Tejocote, El Hondable, La Camotera, La Trinidad, Potrero Redondo, El Pajonal, El Huajuco, La Huasteca and San Antonio de la Osamenta [21]. The sparse settlements throughout the CMNP reflect contrasting socio-economic conditions of its inhabitants. The ejidos, collectively owned tracts, are made up of low to middle class families who live permanently in the area, while half of the private properties within the Park belong to affluent families who typically do not live there on a permanent basis, but use them only on weekends for leisure. Most of the settlements within the CMNP are located in piedmont scrub and pine-oak forest areas, and only a few of them are present in the driest zone, covered by xerophyllous and rosetophyllous scrub.

The contrasts in topography, climate and soil types within the CMNP determine a heterogeneous vegetation mosaic, each plant community composed at times of hundreds of species. Many of these plants are used by resident people for different purposes: as food, medicine, trade goods, forage, and other uses. Throughout the year, especially on weekends, it is common to see many residents selling their products along the roads leading into the CMNP, especially fresh fruit (peaches, apples, plums, pears, prickly pears, apricots), fruit liquors, candies made out of fruit, breads, medicinal plants, firewood, ornamental plants, etc. Despite its high plant diversity (almost 1,500 plant species and the multiple uses given to the local flora, little information exists regarding human uses of the plants in this area [22][23][24][25]. In more general terms, rather few plant uses have been documented in the State of Nuevo León [26][27][28].

Local residents' knowledge about plant uses in the CMNP has resulted mainly from empirical observation and oral transmission from generation to generation. Much of this traditional knowledge is currently being lost, in large part due to the fact that the younger generations move out of the CMNP to work and study in urban areas, especially in Monterrey. The main objective of the present study is to document the traditional knowledge and uses of plants in this part of northeastern Mexico.

The CMNP is located in the west-central part of the State of Nuevo León, covering parts of seven municipalities: Allende, Montemorelos, Monterrey, Rayones, Santa Catarina, San Pedro Garza García and Santiago (25 $41^{\prime}-25^{\circ}$ $02^{\prime} \mathrm{N}, 100^{\circ} 45^{\prime}-99^{\circ} 11^{\prime} \mathrm{W}$ ) (Fig. 1). Its altitude ranges from 600 to 3,400 m above sea level. The climate is markedly seasonal, with a dry period from November to May, and a wet season from June to October [21][29]. The main climate types present within the Park are semi-warm, temperate-subhumid (mesic and temperate areas, above 750 masl), and arid-warm and very arid-semi-warm (dry areas, below 700 masl), with an annual average temperature of $3^{\circ}$ to $18^{\circ} \mathrm{C}$ in the mesic and temperate areas, and $18^{\circ}$ to $22^{\circ} \mathrm{C}$ in the dry areas, with an annual rainfall between $400 \mathrm{~mm}$ in the dry areas and $1000 \mathrm{~mm}$ in the mesic and temperate areas [29][30].

\section{Methods}

This study was part of a larger project under the title "Flora of the Cumbres de Monterrey National Park, " sponsored by the National Biodiversity Commission (CONABIO, Grant APO-36). All the information regarding plant species, biological forms, habitat, local names and uses was recorded by the authors between April 2004 and April 2006. Ethnobotanical information was obtained through informal interviews conducted during the same period with knowledgeable individuals, ranging in age between 35 and 70 years old. We selected this age group because these generations are most familiar with the different uses 




Figure I

of the regional flora. Three quarters of the group were at least 50 years old. All of the people we interviewed belong to the lower income class and do not have permanent jobs, but carry out different kinds of work along the year: cattle ranching, laying bricks, selling plants, etc. All 95 persons interviewed ( 40 women and 55 men) live permanently in the CMNP; most of them (90) were born in communities within the Park, while the remaining 5 individuals were born in tows nearby (Allende, Montemorelos and Santiago). All the interviews were performed in Spanish, and the informants did not belong to any other linguistic or ethnic group.

We asked our informants which species of plant are used for specific and for general purposes. We took notes during all conversations. No information that was provided to us was left unrecorded, and we have included in this publication all the names and uses of plants that we documented. A voucher specimen of each plant species we collected has been deposited together with all the relevant data in the herbaria CFNL (Linares, N.L.) and ANSM (Saltillo, Coahuila).

Plants collected in the field were brought to the settlements and shown to the people living there to inquire about the common names and uses of each species. In addition, we made frequent field trips with our informants for in situ identification of plants they mentioned in the interviews. Given that the CMNP includes two heterogeneous, well differentiated climatic areas, the temperate zone (which is mountainous and covers $74 \%$ of the total area), and the arid zone (which occurs in inland basins that cover $26 \%$ of the Park), we carried out 65 interviews in the temperate zone and 30 the arid zone. Except for Cannabis sativa ssp. indica and Lophophora williamsii (we took photographic records of both species) which we found preserved in an alcohol solution at doña Anselma's 
house, voucher specimens of all the species recorded in this study were collected by the authors.

\section{Results and discussion}

We recorded 240 species, 170 genera, and 69 families of plants that grow in the CMNP and have at least one use in the local folk culture. 211 species were recorded in the temperate zone, and 105 in the arid zone, while 74 species grow in both areas. Almost all plants in both climatic zones have only one common name except for two species, Berberis gracilis var. madrensis (called cuasia and palo amarillo), and Geranium seemanii (geranio and alfilerillo). Most of the Agave, Pinus, Quercus and Euphorbia species are called maguey, pino, encino and golondrina, respectively. Most of the Mammillarias are called chilitos, all species of Chenopodium and Teloxys are known invariably as epazote, and orquídea is applied to all species in the family Orchidaceae. On the other hand, in a few cases the same common name is applied to different genera of the same family, such as poleo (Agastache and Hedeoma) and yerba de la gallina (Commelina, Gibasis and Tradescantia), or even to genera in different families, such as siempre viva (Selaginella, Sedum and Echeveria) and salvia (Salvia and Croton).

A total of 146 different uses were recorded, most of them (98) falling under a broader category of medicinal utility, while the rest (48) refer to various purposes, mainly for human consumption, fodder for domestic animals, firewood, construction materials, live fences, etc. [see Additional file 1]. Most of the information regarding the use of cultivated plants as home remedies was obtained from women, while most of the data on non-medicinal uses of wild plants were provided by older men. In general, most of the women we spoke to stay at home most of time, where the main activities are cooking, taking care of the children, tending gardens of edible and ornamental plants, etc., so they are most familiarized with cultivated plants and their uses, while men carry out field activities such as taking care of livestock, cutting firewood for home use and for sale, sowing plants, collecting fodder for the animals, etc., so they are in closest contact with wild plant and their uses. However, one particular lady known as doña Anselma, one of the most important matronas (midwives) and curanderas (healers) in the region, has a notable empirical knowledge of the uses of both cultivated and wild plants, and is widely recognized as a reliable healer. Many of the locals prefer to visit her rather than the physicians working at the modern health clinics within the CMNP, and this is partly due to the fact that besides her comprehensive knowledge of plant uses, she has had some academic training as well, having taken a childbirth assistance course.
People in the group from 50 to 75 years of age or older gave us information on $95 \%$ of the total plant uses, while individuals 35 to 49 years old provided information on $45 \%$ of the plant uses. As a general rule, younger residents in the area know much less about the uses of plants than older people.

The families with the highest number of genera used in the local folk culture are the Asteraceae (14), Cactaceae (12), Fabaceae (11), Rosaceae (8), Lamiaceae (7), Agavaceae (6) and Caesalpiniaceae, Mimosaceae, Solanaceae and Orchidaceae, each of which we found to have five useful genera. On the other hand, the families with the most numerous useful species in the region are the Cactaceae (25), Lamiaceae (16), Asteraceae (15), Agavaceae (12), Fabaceae (11), Rosaceae (10) and Euphorbiaceae and Mimosaceae, with eight useful species each. The families with a higher number of uses are the Asteraceae (41), Lamiaceae (38), Cactaceae (37), Agavaceae (21), Mimosaceae (20), Rosaceae (18), Fabaceae (15), Euphorbiaceae (14), Caesalpiniaceae (9), Crassulaceae (8), Solanaceae (8) and Commelinaceae (6). The species with the most diversified uses are Aloe vera (12), Marrubium vulgare (8), Agave bracteosa and Zea mays (7), Tagetes lucida and Allium sativum (6), and Acacia farnesiana, Litsea glaucescens, Matricaria recutita, Machaeranthera psamophila, Mirabilis jalapa, Mentha spicata and Smilax bona-nox, Ageratina sp., Artemisia mexicana, Teloxys ambrosioides, Cupressus arizonica, Ebenopsis ebano, Lantana macropoda, Opuntia sp., Prosopis glandulosa var. glandulosa, Rosa serrulata, Rosmarinus officinalis, Ruta graveolens and Taxus globosa (5).

\section{Homegardens}

We found 59 species cultivated in local gardens for various purposes, 20 of which grow wild in the area. All the women we interviewed cultivate at least three plant species in their gardens for various uses; the most common species in these gardens are Mentha spicata, Pelargonium odoratissimum, Ficus carica, Ruta graveolens, Punica granatum, Aloe vera, Foeniculum vulgare, Matricaria recutita, Agave spp., Opuntia spp. and Hedeoma drumondii. The exchange of cultivated plants between households, especially those used medicinally or as ornamentals, is a common practice among women living inside the Park.

\section{Type of use}

Out of the 98 medicinal uses of plants we recorded, the most common are the control of colic (21), diabetes (19), stomachaches (9) and headaches (8); in all these cases, plants are boiled and ingested orally. Infusions play a very important role in local folk medicine: they represent the main type of remedy against various kinds of illness in both climatic areas, the temperate and the arid zones. Most infusions are prepared boiling the leaves, flowers 
and parts of the stems. In most cases, a single plant is used, but in a few instances, two or more species are mixed together to brew a tea. Even though they trust the efficacy of traditional remedies, some people we spoke with, especially those who live near a health clinic or are in close contact with modern medicine, combine empirical and scientific knowledge to treat their maladies (headaches, stomachaches, colic, etc.), and they will drink an herbal infusion along with two aspirins, tylenols, mejoral pills or other commercial medicines. They told us, however, that pills can only control the pain, whereas infusions will cure the illness, though they also said that both kinds of remedies are sometimes needed for a sick person to really get well.

Most of the people we interviewed (65) dry and store their medicinal plants to use them later; the dried parts are mostly the leaves, stored in paper bags or hung in bundles from the ceiling. Two common medicinal species, Lophophora williamsii and Cannabis sativa ssp. indica, are usually kept in alcohol (70-90\%), since these plants cannot be cultivated, as they are forbidden by law, however, to avoid any type of punish for the government authorities, these plants must be kept in alcohol and also in small quantities. Wild and cultivated edible plants are an important part of the diet of people living in the region. Thirty nine different species are used for this purpose, foremost among them the plants (21 species) that provide fruit, whether it is eaten raw or cooked, belonging to the genera Echinocereus, Cucurbita, Sechium, Persea, Morus, Ficus, Punica, Crataegus, Fragaria, Prunus, Lycopersicon and Physalis. Fruit plants are followed in importance by species (8) with edible leaves, which belong to the genera Amaranthus, Rorippa, Tillandsia, Chenopodium, Teloxys, Rumex and Portulaca; plants (8) that bear edible seeds or stems (Opuntia, Pisum, Vigna, Allium, Ebenopsis and Avena); and species (2) with edible flowers (Yucca).

A focus on local use, i.e., the tending of different kinds of plants in a home garden to fulfill the family's needs, is more prevalent in households of the temperate area than in the arid zone. In the former area, some residents harvest much of their own food in their gardens; we recorded 53 domestic units that show different combinations of medicinal, food, beverage, flavoring, firewood and ornamental species. The most common combinations of useful plant were medicinal-food and medicinal-firewood, followed by medicinal-ornamental. In most of the 95 households we visited for our interviews, we recorded several combinations of uses. In most of these gardens, people harvest tomatoes (Lycopersicon esculentum), peas (Pisum sativum), prickly pears (Opuntia ficus-indica) and celery (Apium graveolens) for food; chamomile (Matricaria recutita), rue (Ruta graveolens), mint (Mentha spicata) and aloe (Aloe vera) for medicine; maguey (Agave asperrima) for a beverage and a syrup; fennel (Foeniculum vulgare) and basil (Ocimum basilicum) as flavoring herbs; pitch pine (Pinus teocote) and oaks (Quercus spp.) as firewood, and palo casita (Cornus florida), chilitos (Mammillaria spp.) and siempreviva (Sedum spp. and Echeveria strictiflora) as ornamental plants.

\section{Economic botany}

Besides these uses, people living in the temperate zone have developed a small industry canning the fruit (conservas) of cultivated species, mainly peaches, apples, pears, apricots and plums. They also produce fruit liqueurs and a beverage obtained from an agave (aguamiel). To make conservas, cultivated fruits are boiled in water and sweetened; after boiling, fruits are immediately packed in glass flasks. The canned fruit keeps well for a long time, and local people sell it throughout the year. Homemade sweet fruit liqueurs (apple, pear and capulín) as well as sotol (a distilled liquor made from Dasylirion sp.) have a high demand from Park visitors. Aguamiel is obtained scraping a cavity $15-20 \mathrm{~cm}$ in diameter in the center of a mature maguey; once a day, the sap that gathers in the cavity is collected with a cup and refrigerated in plastic containers to be sold. At times, aguamiel is boiled slowly for 3-4 hours to prepare a syrup, a more elaborate product that fetches a higher price. Conservas, fresh cultivated fruits, aguamiel, liqueurs and agave syrup are the main products sold by CMNP residents along the seasons. Except for wild Cactaceae (Mammillaria spp., Echinocereus spp., Ariocarpus retusus and Astrophytum capricorne), Crassulaceae (Echeveria strictiflora) and Agavaceae (Agave victoriae-reginae and A. bracteosa) that are offered for sale as ornamentals, people living in the arid zone do not sell any local products as a means of subsistence. However, they do consume various cactus fruits, especially those of Echinocereus (pitayas) and Opuntia (tunas) species.

Several plants are widely used as animal fodder: residents of the temperate zone who own livestock, mainly bovines, commonly feed them with wild species such as Opuntia engelmannii (stems), Dalea bicolor (leaves), Eysenhardtia texana (leaves), Quercus spp. (leaves and acorns), Acacia spp. (leaves), Leucaena spp. (leaves) and Prosopis glandulosa (leaves and pods). In addition, three cultivated plants are used extensively for this purpose:Medicago sativa, Vicia villosa and Opuntia ficus-indica. Medicago sativa is not widely cultivated in the area, but people buy it in the nearest town, Santiago. In recent years, Vicia villosa is being cultivated as forage in some of the most productive agricultural areas within the CMNP, such as Laguna de Sánchez. Plantago major is a weedy species that grows very commonly on fallowed plots in the highland valleys; it is widely used to feed horses and donkeys, and people harvest it in the fields to take home to feed their animals. Pigs are mainly fed acorns (Quercus spp. fruits), which local 
people consider to be excellent fodder, allowing swine to grow large and healthy, improving the profits when they are sold. The most common prickly pear that is exploited as animal feed is Opuntia ficus-indica; since this species lacks prickles, all that people need to do is cut the pads into smaller parts and give them to the cattle. Residents of the dry zone take their livestock (mainly goats and cows) to graze in the mezquite (Prosopis glandulosa var. glandulosa) bottomlands, where they feed on the pods and leaves, as well as on wild prickly pears (Opuntia engelmannii). On cultivated tracts, once corn (Zea mays) has been harvested, the dried stems with leaves and tassels are gathered and stored in packs to feed cattle during the winter season. Echinocactus platyacanthus (biznaga burra) plays an important role at times of severe drought because it is used as a source of water and food for livestock, mainly goats: residents simply slice up the plants and feed them to the animals.

\section{Ornamental plants}

The ornamental use of wild and cultivated plants is seen more frequently in the temperate area, where the higher diversity and prevalence of appealing herbaceous, shrubby and arboreal life forms have attracted the attention of residents, who have taken many of those species into their gardens as ornamentals for their own enjoyment and also, in few cases, to propagate and sell them in small scale operations. The ornamental plants that are cultivated most commonly in the Park are Ficus carica, Punica granatum, Acer negundo, Echeveria strictiflora, Begonia gracilis, Mammillaria spp., Agave bracteosa, Lonicera pilosa, Sambucus mexicana, Cupressus arizonica, Persea americana, Carya ovata, Rosmarinus officinalis, Litsea glaucescens, Aloe vera, Pteridium aquilinum, Prunus persica, Lantana camara and Vitis berlandieri. Echeveria strictiflora (siempreviva) and Agave bracteosa are the wild plants most frequently sold as ornamentals in the CMNP. Some orchids, especially Dichromanthus cinnabarinus and Malaxis macrostchya, are also used as decorative plants, but are less common. Most of the ornamental species in the arid zone are cultivated, such as Aloe vera, Bougainvillea glabra, Rosmarinus officinalis, Punica granatum, Ficus carica, Opuntia ficusindica, Marrubium vulgare and Mentha piperita, but some wild plants are also used for this purpose, such as Agave bracteosa, Yucca carnerosana and Chilopsis linearis. The epiphyte Tillandsia usneoides is collected mainly from Quercus spp. trees in the mountains during November and December to be used as a decoration under Christmas trees; it is compressed into packs that weigh 15 to $20 \mathrm{~kg}$ to be transported and sold in Monterrey. In spite of the huge quantities available of this species and its easy marketing, few people collect this plant today because of the low price paid for it: 50 centavos ( 0.5 pesos), approximately equivalent to 5 cents US cy, for $1 \mathrm{~kg}$. Buyers are very picky and will only pay even that low a price for packs where the stems remain green, not if they have turned grey. Currently year, only 5 persons are dedicated to gather it, each one collect approximately 700-1000 kg during the two months of that activity, which represents less than $0.01 \%$ of the total resource of this plant, in such a way, its populations have a sustainable management.

Despite its proximity to Monterrey (25 to $50 \mathrm{~km}$ away), which is one of the most modern and industrialized cities in Mexico, most of the permanent residents in the ejidos and small villages in the CMNP, who are the poorest inhabitants of the Park, still conserve part of their traditions concerning the uses of wild and cultivated plants. Undoubtedly, a good part of their ethnobotanical knowledge has been lost during the last 100 years. Elderly residents told us that their parents were more knowledgeable about plants since their survival depended on them, and they consider they know only a small fraction of what their parents did. They also commented on how the younger generations are not very interested in the different uses of plants, as they prefer to go to the nearest cities to study or to look for a job. At present, the local folk knowledge of plant uses is vanishing, not only because urbanization and modernity are unavoidably encroaching on the CMNP, but also because young people are migrating away, looking for new life perspectives outside of the Park. For them, knowledge about plants gets reduced to asking their parents for a beautiful plant in the temperate zone to take as a gift for a friend in the city, or where to find peyote in the dry zone for an aunt in Monterrey who suffers from arthritis.

Twelve percent of the useful plants reported for the semiarid and temperate areas of Tamaulipas [31] are found in CMNP, especially shrubs and herbaceous species used for medicines, food and fuel. In addition, CMNP has strong affinities in species diversity as well as plant uses with the arid central region of Mexico, where 206 useful native shrub species [32] (in 109 genera and 42 families) have been reported, with more than 220 different uses. Of these, the most diverse families are the Leguminosae (52 species), Fagaceae (Quercus, 15) and Asteraceae (12), and the main uses are for medicines, construction, textiles and food. The two areas share $76 \%$ of families, $49 \%$ of genera, and $44 \%$ of species. The genera with similar uses are, for construction: Dasylirion, Cupressus, Parkinsonia, Acacia, Ebenopsis, Prosopis, Quercus, Pinus and Abies; for medicinal use: Rhus, Artemisia, Acacia, Tecoma, Arbutus, Salvia, Buddleja, Cowania, Prunus, Salix, Taxodium and Larrea; for food: Echinocactus, Ebenopsis, Carya, Crataegus, Prunus and Celtis; for fuel: Cupressus, Parkinsonia, Acacia, Ebenopsis, Mimosa, Prosopis, Quercus, Pinus and Taxodium; for ornamental use: Bauhinia, Ebenopsis, Pinus, Salix and Taxodium; and for fodder: Acacia, Leucaena, Prosopis, Eysenhardtia and Quercus. In a similar way, several studies carried out in 
southern Mexico reveal the nation's rich plant diversity and the extensive knowledge of useful plants. In the State of Hidalgo, 101 species are used for multiple purposes, especially for medicines (47\%) and food (22\%) [33]. In the Tehuacán-Cuicatlán Valley (Puebla), 49 species of medicinal plant [34] have been recorded in 48 genera and 28 families, most of them wildflowers (48\%), $28 \%$ in cultivation, and $24 \%$ acquired in markets. Almost all of these species $(90 \%)$ are ingested as an infusion. Most of the cultivated plants used in this area are present and used for similar purposes by inhabitants of the CMNP, mainly those belonging to the genera, Aloe, Opuntia, Mentha, Ocimum, Prosopis, Psidium, Bouganvillea and Ruta. Along the coastline of Oaxaca, useful plants are used as medicines (80 species) and for construction (19), wood (19) and forage (5), and most commonly belong to the Asteraceae, Leguminosae, Poaceae, Solanaceae, Cucurbitaceae, Rutaceae and Bignoniaceae [35]. In Quintana Roo, 83 useful species have been recorded, most of them arborescent species [36]. The main uses are for medicine, construction, food and fuel, and the main families are the Leguminosae, Rubiaceae, Verbenaceae and Sapotaceae.

As in other regions of Mexico, the main uses of plants in CMNP are for medicines, food, construction and ornaments. People inhabiting the CMNP use herbaceous plants as medicines and food in the same way they do in other regions of Mexico; shrub species are mainly used for fuel, food and ornaments, while arborescent species are used mainly for construction and fuel. Only a few wild arborescent species produce edible fruits, in contrast to the larger number of edible fruits reported for southern Mexico [37].

One of the striking differences between southern Mexico and the CMNP is the number of arborescent species with multiple uses. CMNP has a low diversity and fewer uses of such species than southern Mexico. Arborescent species in CMNP represent only 11\% (27 species) of useful plants, while in some areas of southern Mexico, a third or more are arborescent with multiple uses. Arborescent species in CMNP are mainly used for fuel and construction, while $54 \%$ of arborescent plants in some areas of Mexico are used for at least 75 different purposes, especially for medicines, construction, food, fencing, fuel, industry, wood, oils, psychotropic substances, dyes and handcrafts [36]. Arborescent legumes play an important role as edible plants, $54 \%$ of 86 species recorded in southern Mexico being used for this purpose, especially species of Acacia, Caesalpinia, Enterolobium, Erythrina, Inga, Leucaena, Pithecellobium and Prosopis [38]. Most of these genera are used as fodder in CMNP. In the La Mancha Natural Reserve, Veracruz, 69\% of the arborescent species are useful, mainly being used for construction, fencing, fuel, medicines and ornamental purposes [39].

\section{Additional material}

\section{Additional File 1}

Table 1. List of plant species used in the Cumbres de Monterrey National Park, Nuevo León, Mexico.

Click here for file

[http://www.biomedcentral.com/content/supplementary/17464269-3-8-S1.pdf]

\section{Acknowledgements}

This study was partially financed by a grant (No. APO-36) from the Comisión Nacional para el Conocimiento y uso de la Biodiversidad (CONABIO). We thank Claudia Platas, Erika Zamora C., Margarita Barba P. and Miguel González B. for collaborating in the field work. This work would not have been possible without the help of all the residents we interviewed in the area. Alejandro de Ávila Blomberg of the Jardín Etnobotánico de Oaxaca and Nicolas Reid rewrote the manuscript for us, correcting the English spelling, grammar and style.

\section{References}

I. Muller $\mathrm{CH}$ : Relation of the vegetation and climatic types in Nuevo León, México. Amer Midl Nat 1939, 2 I:687-729.

2. Rojas-Mendoza P: Generalidades sobre la vegetación del estado de Nuevo León y datos acerca de su flora. In PhD thesis Universidad Nacional Autónoma de México; 1965

3. Rzedowski ]: Vegetación de México. México 1978.

4. Valiente-Banuet $A$, Flores-Hernández $M$, Dávila $P$ : The chaparral vegetation in Mexico under nonmediterranean climate: The convergent and Madrean-Tethyan hypotheses reconsidered. Amer Jour Bot 1998, 85: I 398-1408.

5. Perry JP: The pines of Mexico and Central America Timber Press, Oregon, USA; 1991.

6. Miranda F, Hernández XE: Los tipos de vegetación de México y su clasificación. Bol Soc Bot Méx 1963, 28:29-179.

7. Beaman $\mathrm{JH}$, Andresen JW: The vegetation, floristics and phytogeography of the summit of Cerro Potosí, México. Amer Midl Nat 1966, 25: I-33.

8. Farjón A, Pérez de la Rosa J, Styles BT: Guía de campo de los pinos de México y Centro América Royal Botanical Gardens, England; 1997.

9. Scott-Morales L, Estrada E, Chávez F, Cotera M: Continued decline in geographic distributions of the Mexican prairie dog (Cynomys mexicanus). Jour Mammal 2004, 85:1095-I I0I.

10. García AA, González S: Flora y vegetación de la cima del cerro EI Potosí, Nuevo León, México. Acta Botánica Mexicana 199I, 13:53-74.

II. Hersch-Martínez P: Commercialization of wild medicinal plants from southwest Puebla, Mexico. Econ Bot 1995, 49:197-206.

12. Ward O: Políticas de bienestar social en México, 1970-1989: México 1989.

13. Baytelman B: De enfermos y curanderos, medicina tradicional en Morelos Instituto Nacional de Antroplología e Historia, México; 1986.

14. Bye $R$, Linares $E$ : The role of plants found in the mexican markets and their importance in ethnobotanical studies. J Ethnobio 1983, 3:1-13.

15. Sentíes GA: Plantas medicinales y sistemas tradicionales de curación del Valle de Tehuacan, Puebla. In MSc thesis Universidad Nacional Autónoma de México; 1984.

16. Soto $\mathrm{N}$ : Las plantas medicinales y su uso tradicional en la Cuenca del Río Balsas; estados de Michoacán y Guerrero. In MSc thesis Universidad Nacional Autónoma de México; 1987.

17. Benz BF, Cevallos J, Santana F, Rosales J, Graff M: Losing knowledge about plant use in the Sierra at the Manantlan Biosphere Reserve, México. Econ Bot 2000, 54:183-191.

18. Frei B, Baltisberger M, Sticher O, Heinrich M: Medical ethnobotany of the Zapotecs of the Isthmus-Sierra (Oaxaca, México): documentation and assessment of the indigenous uses. J Ethnopharmacol 2000, 62: I49-165. 
19. Cáceres A, Girón LM, Freire V: Plantas de uso medicinal en Guatemala: I. Detección etnobotánica y bibliográfica. USCA 1990, 9:.

20. Balick M, Arvigo R, Romero R: The development of an ethnobiomedical forest reserve in Belice: its role in the preservation of biological and cultural diversity. Con Bio 1994, 8:316-317.

21. INEGI: Síntesis geográfica del estado de Nuevo León Instituto Nacional de Estadística Geografía e Informática. México; 1986.

22. Alanís MC, Lara-Ochoa F, Rodríguez EB: Plantas medicinales de México, su composición, usos y actividad biológica. In MSc thesis Universidad Nacional Autónoma de México; 1999.

23. Bernal HJ: Evaluación del uso tradicional de la vegetación en la cuenca del Río Casillas, Municipio de Rayones, Nuevo León, México. In BA thesis Universidad Autónoma de Nuevo León; 2004.

24. Linares ME, Flores PB, Bye R: Selección de plantas medicinales de México. México 1988.

25. Martínez M: Las plantas medicinales de México. México 1990.

26. Valdez R, Aguilar A, López ME, Xolalpa S: Herbolaria mexicana. Consejo Nacional para la Cultura y las Artes. México 2002.

27. Márquez C, Lara F, Esquivel B, Mata R: Plantas medicinales de Mexico II. In Instituto de Química, Dirección General de Publicaciones Universidad Nacional Autónoma de México; 1999.

28. Aguilar A, Camacho JR, Chino S, Jacques P, López ME: Plantas medicinales del herbario IMSS. Instituto Mexicano del Seguro Social. México; 1994.

29. García E: Modificaciones al sistema de clasificación climática de Köeppen. 4th edition. Universidad Nacional Autónoma de México. México; 1987.

30. INEGI: Carta de climas, Monterrey, escala I: I 000 000. Secretaría de Programación y Presupuesto, México; 1986.

31. Hernández L, González C, González F: Plantas útiles de Tamaulipas, México. An Inst Biol UNAM Ser Bot I991, 62:1-38.

32. Terrones RT, González C, Ríos SA: Arbustivas nativas de usos múltiples. Celaya, Gto, México; 2004

33. Villavicencio MA, Pérez $B E$, Ramírez $A$ : Plantas útiles del estado de Hidalgo II. Universidad Autónoma del Estado de Hidalgo, Hidalgo, México; 2002.

34. Canales-Martínez M, Hernández-Delgado T, Caballero-Nieto J, VivarRomo A, Durán-Díaz A, Lira R: Análisis cuantitativo del conocimiento tradicional de las plantas medicinales en San Rafael, Coxcatlán, Valle de Tehuacan-Cuicatlán, Puebla, México. Acta Botánica Mexicana 2006, 75:2I-43.

35. Avendaño HL, Vázquez MA: Plantas útiles de San Juan Cacahuatepec Costa de Oaxaca, México. CONACULTA, México 2003.

36. Téllez VO, Cabrera EF, Linares E, Bye R: Las plantas de Cozumel. Instituto de Biología, Universidad Nacional Autónoma de México; 1989.

37. Pennington TD, Sarukhán J: Árboles tropicales de México. Manual para la identificación de las principales especies. Universidad Nacional Autónoma de México y Fondo de Cultura Económica, México; 1998

38. Arellano MJ: Etnobotánica de leguminosas: notas sobre algunas de las especies utilizadas en la alimentación en México. An Inst Biol UNAM Ser Bot 1987, 57: I23-I42.

39. Castillo-Campos G, Medina ME: Árboles y arbustos de la Reserva Natural de la Mancha, Veracruz. Instituto de Ecología, AC Xalapa México; 2005.

\section{Publish with Biomed Central and every scientist can read your work free of charge}

"BioMed Central will be the most significant development for disseminating the results of biomedical research in our lifetime. "

Sir Paul Nurse, Cancer Research UK

Your research papers will be:

- available free of charge to the entire biomedical community

- peer reviewed and published immediately upon acceptance

- cited in PubMed and archived on PubMed Central

- yours - you keep the copyright
BioMedcentral 